
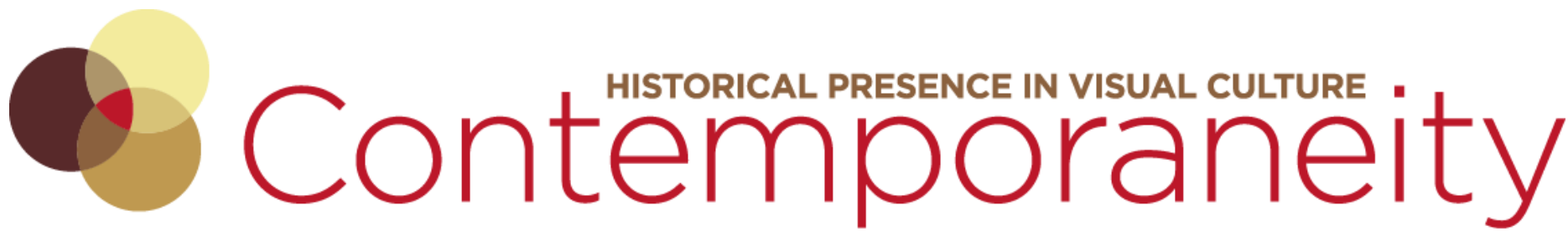

Vol 6, No 1 "Boundless" (2017) | ISSN 2153-5914 (online) | DOI 10.5195/contemp.2017.221

http://contemporaneity.pitt.edu

\title{
Éxodo a la "tierra prometida" Del demonio y otros monstruos en la obra de Juan de Dios Mora
}

\author{
Adriana Miramontes Olivas en conversación con Juan de Dios Mora \\ Introducción por Deborah Caplow \\ Editado por Paulina Pardo Gaviria
}

\section{Sobre los autores}

Juan de Dios Mora es grabador y docente en la Universidad de Texas en San Antonio, donde comenzó a enseñar pintura, dibujo y grabado en 2010. Mora es un artista prolífico cuyos grabados han sido publicados en numerosos sitios incluyendo los catálogos New Arte Nuevo: San Antonio 2010 y New Art/Arte Nuevo San Antonio 2012. Este año su obra se exhibió en distintos lugares incluyendo el Museo de Arte McNay en San Antonio, Texas en Juan Mora: Cultural Clash (Juan Mora: Choque Cultural, junio 8 a agosto 13 de 2017) y en el Centro de Arte the Cole en la Galería Reavley en Nacogdoches, Texas, en Juan de Dios Mora. En 2016, Mora participó en la exhibición colectiva Los de abajo: Garbage as an Artistic Source (Los de abajo: la basura como una fuente artística) en el Centro Cultural Guadalupe en San Antonio (de junio 10 a julio 29 de 2016). Mora también ha sido curador de la exhibición Print It Up por varios años, organizada por el artista en el área del centro de San Antonio dándoles una visibilidad sin precedentes a numerosos artistas. Para esta exhibición Mora guía y aconseja tanto a estudiantes como a exalumnos sobre el proceso de exhibición, desde cómo crear un portafolio, enmarcar e instalar obras, hasta realizar contratos con galeristas y vender las obras al público.

Adriana Miramontes Olivas es estudiante de doctorado en el Departamento de Historia del Arte y Arquitectura en la Universidad de Pittsburgh. Completó su licenciatura en la Universidad de Texas de El Paso y la maestría en la Universidad de Texas de San Antonio. Sus intereses en materia de investigación incluyen arte moderno y contemporáneo global con un enfoque en Latinoamérica, estudios de género, sexualidad e identidad nacional.

La Dra. Deborah Caplow es historiadora del arte, curadora y autora del libro sobre el ilustrador Mexicano Leopoldo Méndez (Leopoldo Méndez: arte revolucionario y el grabado mexicano, publicado por la Universidad de Texas). Ella enseña historia del arte en la Universidad de Washington, Bothell. Sus áreas de investigación incluyen arte Mexicano del siglo XX, las intersecciones entre arte y política, y la historia de la fotografía. Actualmente hace investigación de grabados contemporáneos en Oaxaca, México. 


\section{Éxodo a la "tierra prometida"}

\section{Del demonio y otros monstruos en la obra de Juan de Dios Mora}

\author{
Adriana Miramontes Olivas, Juan de Dios Mora, y \\ Deborah Caplow
}

\section{Introducción}

Los impactantes grabados del artista Juan de Dios Mora (n. 1984) presentan una interesante intersección de culturas, visiones y experiencias relacionadas a la realidad de los migrantes en su camino hacia los Estados Unidos. Las imágenes de Mora sitúan temáticamente a los migrantes en la zona entre la vida y la muerte que todos deben cruzar en su travesía -la frontera, el desierto, el río y el mar- siempre en riesgo de muerte e invariablemente acompañados por la esperanza y la pérdida. Mora sobrepone imágenes referentes a la historia de México y de su relación con los Estados Unidos, desde la antigüedad hasta el presente. Aun siendo profundamente personales y autobiográficos, los grabados de Mora representan las vidas y las muertes de todos los migrantes.

Análogo a los grabados de José Guadalupe Posada (1852-1913) y de otros miembros del Taller de Gráfica Popular, el trabajo de Mora explora la injusticia y el sufrimiento a través de un vocabulario complejo de signos y símbolos culturales, en este caso tomados directamente de su arraigada relación con México y la migración hacia el norte. Tal como el grabador contemporáneo Artemio Rodríguez (México, n. 1972), quien trabaja en Michoacán y California y crea imágenes con virulentos comentarios sociales, Mora emplea tradicionales técnicas gráficas que han caracterizado el grabado político mexicano por más de cien años. Sus aglomeradas composiciones en blanco y negro combinan un simbolismo fantástico con afinadas críticas sociales; en los grabados de Mora, ingeniosas imágenes humorísticas y sarcásticas se burlan constantemente del poderoso y simpatizan con el oprimido. Y tal como el trabajo del artista oaxaqueño Alejandro Santiago (1964-2013), cuyas esculturas en cerámica de la serie 2501 Migrantes expresan el dolor y la pena de la migración en retorcidas y expresionistas estatuas de mujeres, hombres y niños, las imágenes de Mora operan tanto en el corazón como en la mente y hacen que quien las vea se aproxime a ellas a través de un estudio cuidadoso que resulta en una experiencia emocional.

En los grabados aquí publicados, Mora explora a menudo la temática de dualidad, omnipresentes en el arte mexicano desde su comienzo. En su Rapto del emigrante, el migrante parece suspendido entre la vida y la muerte, entre el cielo y la tierra, mientras que el demonio alado que lo carga es a la vez ángel y diablo, con un talón de águila y una cola de serpiente terminada en un glifo maya. Algunos perros surrealistas los rodean y flotan en el aire, como aquellos pequeños demonios de algunos de los grabados de José Guadalupe Posada. Según Mora, el demonio representa a La Migra (Servicio de Inmigración de los Estados Unidos) y los perros son sus pastores alemanes. Junto con este simbolismo, el grabado está lleno de opuestos: bondad y maldad, vida y muerte, luz y oscuridad, comida y agua, mitos pre-colombinos y católicos. Así mismo, los postes de teléfono pueden ser vistos como cruces que marcan la división que es a la vez frontera y carretera, mientras evoca las tumbas que marcan el camino. El águila, el cactus y la serpiente pueden representar tanto el mito fundador de Tenochtitlán (la Ciudad de México hoy en día), y, por consecuencia, a la nación mexicana. En el grabado Rapto del emigrante en particular estos símbolos están fragmentados como una insinuada referencia a la identidad nacional.

Estas alusiones duales también animan Asunción del emigrante, con las palabras 'alma' y 'cuerpo' enmarcando la figura principal, en tanto que ésta asciende en el aire con los brazos levantados, recordando la Crucifixión. Esta figura está rodeada por una mandorla compuesta por una multitud de querubines sosteniendo botellas de agua y por un intrincado grupo de ángeles, nubes, botellas, una rosa, un fríjol y limones, no como estereotipos, sino como un recordatorio del origen de los migrantes y de las situaciones en las que se encuentran. Los limones, por ejemplo, son una parte esencial de la dieta diaria mexicana y, tal como lo explica Mora, una graciosa referencia a la palabra que los migrantes utilizan para 


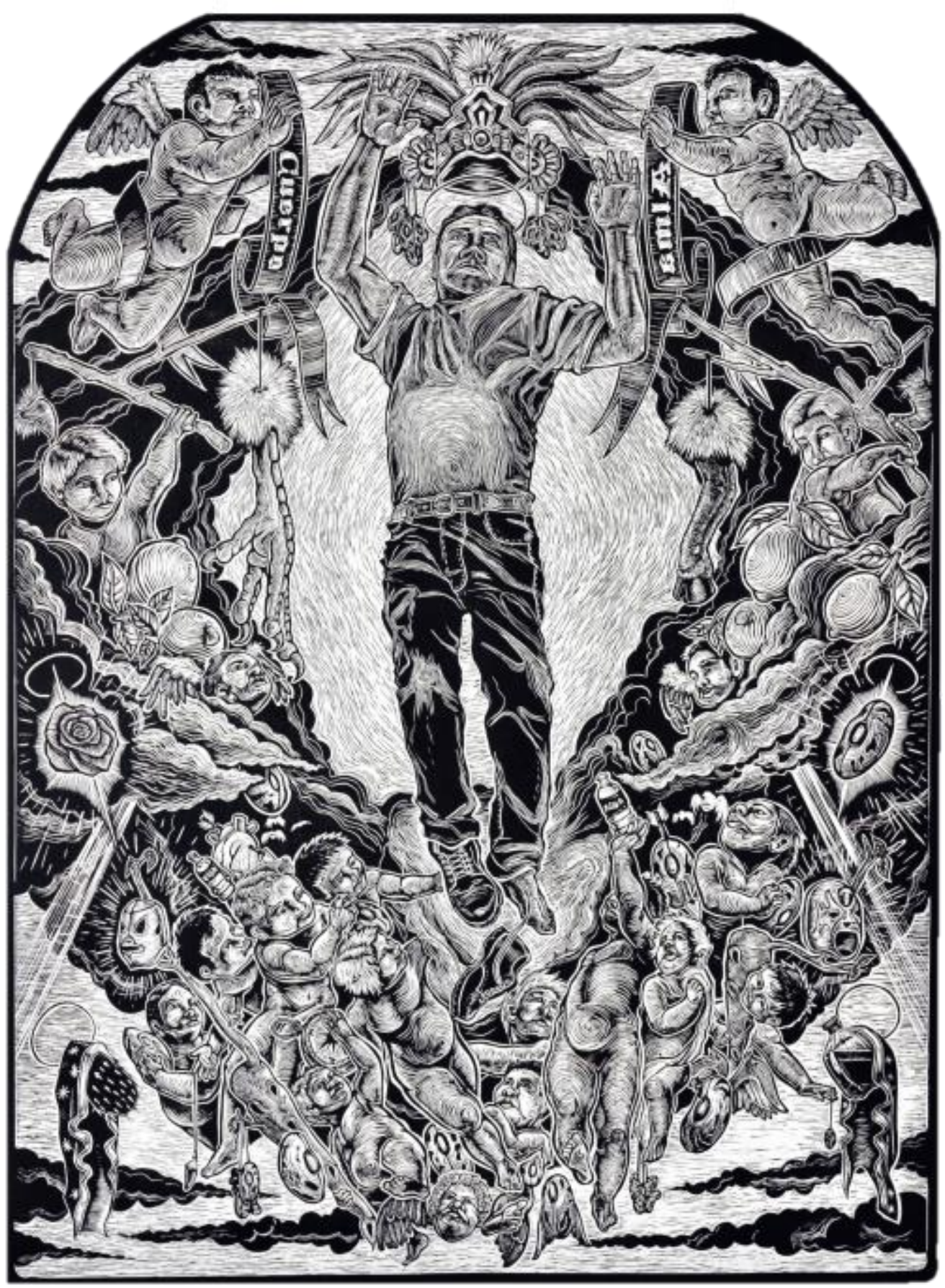

Imagen 1

Juan de Dios Mora, Asunción del emigrante, 2009, linograbado, 24 × 18 1⁄8 pulgadas. 
La Migra ('limones'), que lleva uniformes verdes. Adicionalmente, a un lado Mora incluye las garras de un águila y al otro una pezuña de burro, mientras que una elaborada corona flota en la parte superior sobre la cabeza del migrante, reminiscente de los tocados aztecas. Aquí la Virgen de Guadalupe está reducida a un signo parcial en las esquinas inferiores, su manto cubriendo un cactus en un lado y una botella de agua en el otro, convirtiéndose así en una fuerte alusión a los muchos migrantes que mueren de sed en el desierto en un intento por cruzar la frontera hacia los Estados Unidos.

En Atacado por los pescados Mora incluye el mismo simbolismo. En este grabado, un hombre que se ahoga está rodeado por feroces peces mientras busca salvarse haciendo un gesto de ascendencia, aunque las botellas de plástico, por ligeras, no lo sostendrán y es por el contrario halado hacia abajo por lo que parece ser una botella de agua bendita. El corazón a su lado también se hunde. Los brazos del hombre están levantados, de nuevo en un símbolo de crucifixión, y el grabado provoca una inevitable comparación con la historia bíblica de Jonás, quien es arrojado al mar y debe hacer de su travesía su destino. Como en los otros grabados, el sentido de desánimo y desastre está balanceado por la promesa de la salvación espiritual.

Un peso para el almuerzo, aunque no trata directamente sobre la inmigración, apunta hacia la pobreza y las penurias que llevan a muchos migrantes a dejar su país en busca de mejores condiciones de vida. La dificultad por sobrevivir diariamente está simbolizada en los afiches que anuncian la Lucha Libre y la corrida de toros. La presencia de una ermita con velas encendidas y los brazos en alabanza del mendigo dan la impresión de una salvación potencial, mientras que el perro y el acordeón parecen implicar que la vida en la tierra también tiene recompensas. Como en todas las obras aquí publicadas, en este grabado Mora ofrece esperanza en medio de la adversidad y sugiere un vínculo con un poder superior, infundido con la profunda espiritualidad de la cultura mexicana.

Ahora, más que nunca, estas imágenes tienen gran relevancia y valor al aumentar diariamente la crisis mundial migratoria y la división entre pobres y ricos continúa sacando a miles de sus hogares y arrastrándolos hacia un peligroso e incierto futuro.

Deborah Caplow

Adriana Miramontes Olivas ${ }^{1}$ : El grabado tiene una larga historia de activismo y arte denunciatorio. En la Ciudad de México, el Taller de Gráfica Popular o TGP (fundado en 1937 y en continua actividad hasta el 2010) enfatizó las injusticias cometidas hacia la clase trabajadora, la inestabilidad política y los problemas sociales, así como el esfuerzo colectivo y la acción. El TGP se enfocó en la vida diaria de los pobres y sus artistas demandaban el cambio social. Juan, tu obra también está motivada por la política y es crítica de la economía, del desempleo, tratados de comercio internacionales, seguridad fronteriza e idioma, por nombrar algunos de los temas. ¿Cuál es el propósito de representar tal problemática?

\footnotetext{
1 También agradezco la colaboración y sugerencias de mi colega Rae Di Cicco y los editores de Contemporaneity.
} 
Juan de Dios Mora: Algo que me interesó mucho cuando vine para Estados Unidos desde México fue la discriminación y la inmigración. En México se habla bastante de la inmigración, de una parte, a otra, legal o ilegalmente. Pero cuando vine a Laredo, Texas, eso me impactó. Todo eso me llegó de una forma inesperada, porque estaba joven, así que he hecho estos temas parte de mi obra. ¿Cómo asociar estos problemas con lo del Taller de Gráfica Popular? Me gusta también muchas veces representar las condiciones sociales: hablar de Nuevo Laredo, Ciudad Juárez, la violencia y la inmigración. Mucha gente no quiere comentar sobre estos asuntos, pero están ahí, es evidente. Tengo una pieza, Asunción del emigrante (2009), que es de un inmigrante que se murió. ¿Qué es lo que le pasa a los inmigrantes cuando mueren cruzando la frontera? ¿Qué es lo que le pasa a esas personas? En cuestión de lo físico, se recuperan los cuerpos o los huesos y se llevan a la morgue. Se intenta identificar a los individuos y se espera a que alguien los recupere o se creman. Pero muchas veces las autoridades no mandan los cuerpos a su país de origen porque no saben de dónde vienen. Yo en mi trabajo, como en Asunción del emigrante, trato de darles cierto crédito a todas esas personas que se vienen a Estados Unidos, que lo dejan todo, sus tierras y sus familias en México, Centro y Sur América para echarle muchas ganas, que viajan en busca de mejores oportunidades, pero que muchas veces se quedan en el camino. Entonces Asunción del emigrante refleja a una persona que se murió pero que se va para el cielo. En otras palabras, estoy tratando de darles una cierta importancia a esos eventos que mucha gente ignora o que no les hacen caso.

AMO: Tu obra hace uso de múltiples fuentes. En cuestión de temas, pienso en Guillermo Gómez Peña (n. 1955) y su "arte fronterizo," pero en referencia a la técnica y al contenido la puedo relacionar a los aztecas y sus "guerreros águila" en Mesoamérica, a la Virgen de Guadalupe (1779) de Sebastián Salcedo, y a México en la guerra: los braceros se van a Estados Unidos (1982) de Leopoldo Méndez. Sin embargo, tus grabados son completamente diferentes porque están llenos no solamente de referencias religiosas y crítica social sino también de seres imaginarios como los peces con garras o los perros con cuernos. ¿Cuáles son tus fuentes? ¿Qué es lo que lees o ves para informarte, para inspirarte?

JDM: Cuando llegué al colegio yo no sabía quién era Frida Kahlo ni Diego Rivera. En el rancho no hay nada, yo no conocía nada de arte. Aún en Estados Unidos, todavía en la preparatoria, yo desconocía lo que era el Renacimiento. Fue hasta el colegio en las clases de introducción que me enseñaron sobre las obras de Miguel Ángel, Rafael, Leonardo da Vinci y los grabados de Alberto Durero. Me llamó mucho la atención cómo los artistas hacían al demonio, sobre todo en San Antonio atormentado por los demonios (1470) de Martin Schongauer, porque hay numerosas pinturas y trabajos acerca de la lucha entre el bien y el mal y todos los demonios son diferentes. Pero lo que me gustaba es que a los santos los representaban como seres humanos y los glorificaban, pero los demonios eran distintos, los hacían para asustar. Entonces en Laredo nosotros les hacíamos burla a los agentes de inmigración, la migra, de que eran unos monstruos. Y empecé a comparar a la migra con los demonios del Renacimiento inventando mi propio estilo, creando mis figuras híbridas. Es mi interpretación del demonio y de cómo yo lo veía, lo imaginaba, y ojalá que cause miedo.

El grabado Atacado por los pescados (2009) es de un inmigrante que está tratando de cruzar el río y se está ahogando. Esta obra tiene una historia muy chistosa porque supuestamente unos pescadores encontraron unos cocodrilos en el Río Grande, entonces había rumores en la comunidad, se hacen chistes y chismes. Empezaron a decir que había cocodrilos en el río. Después se comentó que unos inmigrantes que trataron de cruzar de Nuevo Laredo, Tamaulipas, a Laredo, Texas, pusieron el primer pie en el río y empezaron a sentir como que los estaban mordiendo y ise regresaron para México! Pero en realidad eran 


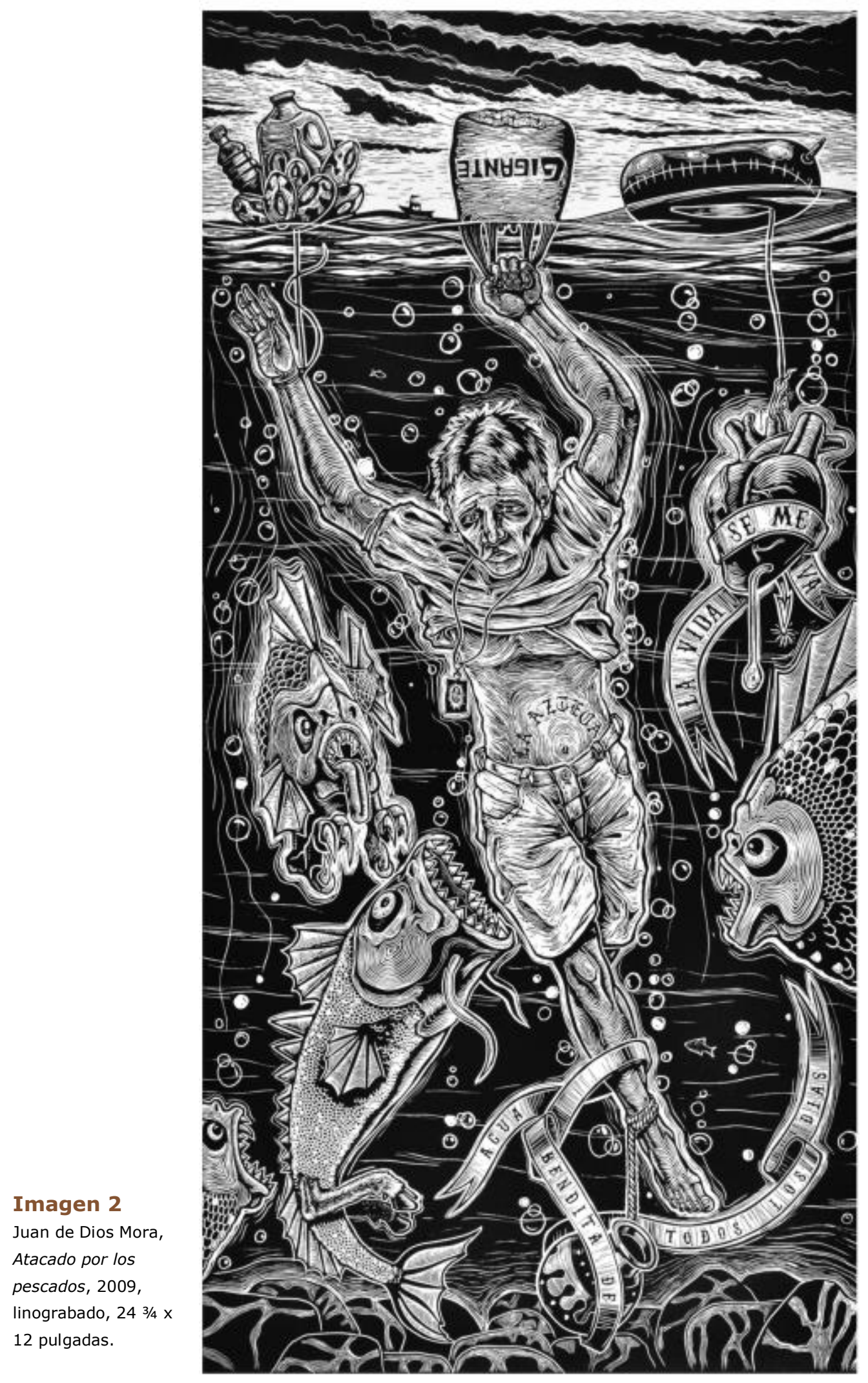


los pescaditos chiquitos que les estaban mordisqueando la piel de los pies, se la estaban comiendo. Por eso hice los pescados así en forma de monstruos, como demonios, para que reflejara un poquito la inocencia de muchos de los inmigrantes pero también comentar sobre su estado psicológico. Porque hay ciertas estrategias que se usan para evitar el cruce ilegal de los inmigrantes. Por ejemplo, la Patrulla Fronteriza tiene tecnología para poder capturar a todos los que intenten pasar ilegalmente, pero también usan el estado psicológico de los inmigrantes. Porque ellos vienen desde muy lejos, tienen un camino largo que recorrer $y$, además, la frontera es otro reto. Trato de representar sus vidas, cómo se la pasan desde sus tierras hasta México y lo que les sucede al llegar a la frontera de Estados Unidos.

AMO: En términos de activismo y protesta, ¿has organizado, participado o planeas establecer alguna organización o taller políticamente activo en San Antonio, en México, o en algún otro lugar?

JDM: Ahorita no, lo que hacía con Andrei Rentería entre el 2014 y el 2015 es que íbamos a educar a la comunidad en las artes. Íbamos a los albergues de los niños que cruzan ilegalmente para los Estados Unidos, que vienen de Centro y Sur América para buscar a sus familias o mejores oportunidades y les enseñábamos un poquito de alguna técnica de arte, de artistas, o una que otra palabra en inglés. Donábamos nuestro tiempo para hacer los talleres y estos proyectos pequeños y realizábamos una o dos obras y los niños aprendían una técnica. No podíamos preguntarles cosas personales, pero ellos nos platicaban las experiencias por las que habían pasado que eran muy muy feas. De una forma u otra me relacioné porque yo también vengo de México.

AMO: Explicas que cuando llegaste a Laredo eras muy joven y que te impactó esta cuestión de la inmigración, ¿qué tan joven eras y por qué fue tal el desconcierto? ¿Era que ignorabas este asunto de la inmigración o por qué creó tanto impacto en ti?

JDM: No es que lo ignorara, es que en México se idealiza venir para los Estados Unidos. Allá lo único que se sabía es que el papá, el tío, o el primo se fueron para los Estados Unidos y están mandando dólares para la familia. iQué bonito! ¿Verdad? Pero ya estando en Laredo me di cuenta de lo complejo de la problemática, gente muere, los acusan, otros también se vuelven locos o pobres. Entonces esos problemas me impactaron y traté de comparar mi vida a la de otros inmigrantes y es muy diferente, aunque mi familia y yo también venimos como una gente trabajadora. Todo eso me ayudó a sacar temas para mi obra, a conocer historias de gente, de sus experiencias de cruzar la frontera.

AMO: Los Estados Unidos es considerado como la "tierra prometida" por muchos inmigrantes. En busca del llamado "sueño americano" cientos de hombres, mujeres y niños intentan cruzar la frontera cada año. El viaje para los inmigrantes indocumentados es por lo regular muy caro y peligroso. Aunque es difícil aportar con cifras específicas, debido a las diferencias según el país de origen y la duración del viaje, es estimado que los migrantes pagan a los "coyotes", o traficantes de humanos, una cifra entre \$429 dólares (únicamente 
para llegar a la frontera) hasta $\$ 2500$ dólares para cruzarla. ${ }^{2}$ En este viaje los migrantes confrontan un sin fin de peligros. Los inmigrantes son amenazados, robados, secuestrados, violados y/o torturados. ${ }^{3}$ Además de estos riesgos, una vez en tierra estadounidense, por ejemplo, en el desierto de Arizona, los inmigrantes están expuestos a temperaturas de $120^{\circ} \mathrm{F}$ durante el verano y a temperaturas congelantes durante el invierno. Tus obras Asunción del emigrante, Atacado por los pescados, Rapto del emigrante (2009), y Un peso para el almuerzo (2010) tratan de la inmigración. En tu opinión, ¿por qué razón cientos de personas intentan cruzar la frontera cada año a pesar de los retos e inseguridades que esto conlleva?

JDM: En lo personal, en México mi papá tuvo muchos problemas económicos, él estaba endeudado. En distintos países se habla del trabajo de menores, pero nosotros desde chiquitos trabajábamos y lo considerábamos como algo normal. Nosotros íbamos para el rancho de mi papá a colaborar en las cosechas y mi papá nos decía saquen hierbas, agarren el azadón, hagan esto, y andábamos en friega, de un lado para otro. Pero nosotros, como te digo, estábamos jóvenes y no percatamos que mi papá estaba en muchos problemas económicos. Entonces llegó un tiempo donde sinceramente mi papá ya no podía más con la deuda y tampoco con el estado psicológico, y decidió dejar todo en México e irse a los Estados Unidos. La primera vez dice mi papá que para él fue muy difícil cruzar porque tenía que encontrar al "coyote" y también juntar el dinero para pagar al traficante. Él comenta que para cruzar la frontera sí tuvo mucho miedo, pero en ese tiempo era más fácil. Ahorita con la tecnología moderna es altamente complicado. Para cruzar, mi papá caminó por días, llegó a una caballeriza y en el abrevadero estaba el agua bien sucia, pero cuenta mi papá que tenía bastante sed y que con las dos manos agarró el agua y la bebió así (Juan hace un gesto y se lleva las manos hacia la boca). Recuerda mi papá que le sabía icomo refresco! (risas). Pero lo más importante de todo esto es que los inmigrantes se mudan por la economía. Mi papá tiene una familia grandísima, éramos cinco hermanos y con mi mamá seis, entonces ya no podía, mi papá ya no sabía qué hacer. Y en México, en el rancho, todos hablaban de Estados Unidos, el Norte, el Norte, el Norte, y el "sueño americano", el dinero, los dólares, los dólares. Mi papá, pues siendo una persona responsable y también valiente, vino para acá y trabajó, juntó dinero y después se regresó para México por un año. Luego decidió volver otra vez para Estados Unidos. La tercera ocasión que atravesó la frontera para Estados Unidos, entró la reforma migratoria y fue cuando nos arregló la residencia a todos nosotros, pero fue muy difícil para mí y mi familia. Se sentía muy diferente la cultura aquí, fue una experiencia bonita, pero mi papá abandonó su país por la economía. Otras personas se mudan por la violencia.

\footnotetext{
2 Esta cifra es hasta el 2014. Jeremy Slack and Howard Campbell "On Narco-coyotaje: Illicit Regimes and their Impacts on the US-Mexico Border," Antipode 48, no. 5 (2016), 1393; Joseph Sorrentino, "Mordiendo la mano que nos alimenta: trabajadores migrantes en Nueva York sin gozar derechos básicos," en Rufino Domínguez Santos, "Tiempos de Obama: Migración," La Jornada del Campo no. 17, 13 febrero 2009, http://www.jornada.unam.mx/2009/02/13/migracion.html

${ }^{3}$ Tal es el caso de la masacre ocurrida en San Fernando en Tamaulipas México que recibió atención internacional y que tuvo lugar en agosto del 2010 en la que 72 inmigrantes de diversas nacionalidades fueron encontrados muertos.
} 
AMO: Ha habido numerosos intentos para prevenir el paso de inmigrantes indocumentados a los Estados Unidos en su frontera con México. Esto ha creado el llamado "efecto embudo" en el que los migrantes usan rutas alternativas en áreas remotas para evitar ser detectados y detenidos en lugar de los tradicionales puntos urbanos de cruce. Esto los lleva a zonas peligrosas como los desiertos del sur de Arizona. ${ }^{4}$ En consecuencia, esto ha incrementado los riesgos asociados con el cruce de la frontera $y$, aunque el número de muertes en la frontera E.U.-México es desconocido, las estadísticas de la Patrulla Fronteriza demuestran que, del 10 de octubre de 1997 al 30 de septiembre de 2013, hubo más de 6029 muertos. ${ }^{5}$ En tu grabado Rapto del emigrante vemos el paisaje dividido en dos por un camino. También hay un hombre joven cuyo cuerpo está siendo perforado por un alambre de púas. En una mano sostiene una botella con agua, en la otra sostiene una bolsa de Soriana, la compañía de supermercados mexicana, quizá con provisiones de comida. El joven aparece en el aire peleando con una criatura híbrida, pero a pesar de esto, él no suelta su botella de agua ni su fuente de alimento. ¿Podrías explicar en dónde están? y ¿podrías platicarnos de las diferentes partes que conforman este monstruo, como el diferente pelaje, diversas plumas, los cuernos y las garras?

JDM: En el Rapto del emigrante, el demonio es la Patrulla Fronteriza y los perros son los que traen los oficiales, los de raza alemana. En el sol está un maíz y arriba de éste hay un frijol. El maíz lo uso como un símbolo de fertilidad y es una metáfora de nosotros, inmigrantes, que venimos a Estados Unidos en busca de una nueva vida. El maíz cuando uno lo planta, da de comer y también puede dar dinero, se puede vender. Entonces es una metáfora de nosotros los que nos mudamos para acá, donde podemos comer, ganar dinero y, asimismo, enviarlo para que nuestras familias sobrevivan en México. Entonces el maíz allí arribita es como un ídolo, tiene un círculo, la aureola, y adentro de ésta se encuentra un frijol, en referencia al término "frijolero," porque a mí me empezaron a decir "frijolero". Así que el frijol lo uso en forma cómica, pero también de una forma política. A mí no me afecta, lo adopto a manera de fortalecimiento, lo que nos dicen lo podemos cambiar y convertir en algo positivo, por eso tengo el frijol.

En el Rapto del emigrante la figura híbrida representa al diablo, es un demonio, la Patrulla Fronteriza. Tiene las patas de un águila, los cuernos de una gacela y además aparece con cuatro orejas. El estilo es como del Renacimiento, ya que cuando los artistas hacían los monstruos los dramatizaban, los representaban de cierta forma para asustar al público. Entonces aquí hice eso yo también: lo exageré, el demonio tiene una piocha para hacerlo más tenebroso, para espantar. En la mano izquierda sostiene un garrote, representando los que usan los oficiales de la Patrulla Fronteriza, y en la mano derecha este demonio sujeta un alambre de púas que a la vez está amarrando a la otra persona para transportarlo hacia arriba. El alambre asimismo cuenta con unos hilos y de ahí cuelgan frijoles que son una representación de nosotros, los inmigrantes, los frijoleros. La cola del demonio es maya, un jeroglífico, y también de ahí están colgando unos frijoles.

En el Rapto del emigrante, abajo aparece la imagen de la Virgen María, un ícono de nosotros, es para dar aliento, para sobrevivir, para echarle ganas a la vida, una motivación

\footnotetext{
${ }^{4}$ Daniel E. Martinez, Robin C. Reineke, et al. "Structural Violence and Migrant Deaths in Southern Arizona: Data from the Pima County Office of the Medical Examiner, 1990-2013," Journal on Migration and Human Security 2, no. 4, (2014), 262.

${ }^{5}$ Cornelius, 1998, in Daniel E. Martinez, Robin C. Reineke, et al., 258.
} 


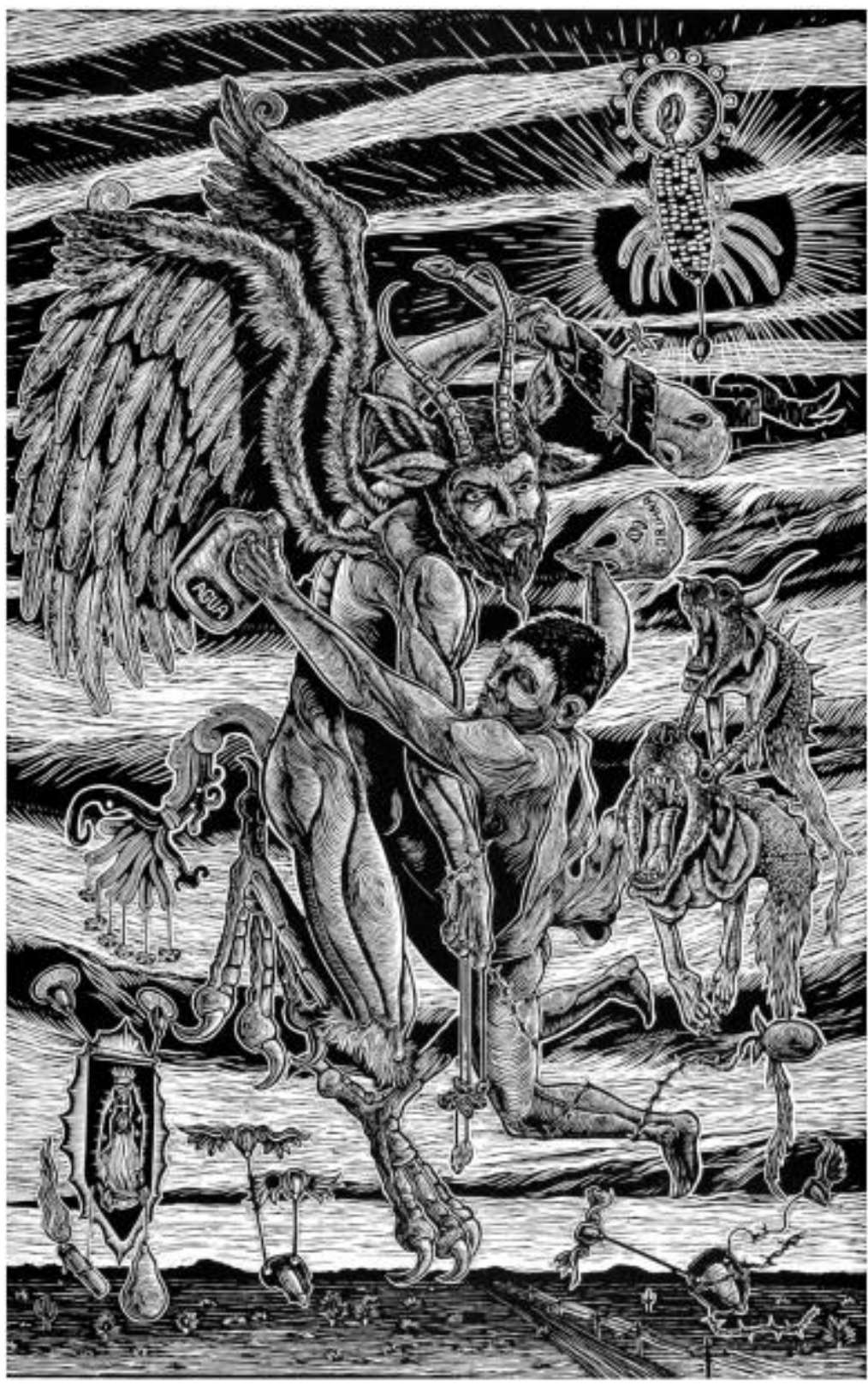

\section{Imagen 3}

Juan de Dios Mora, Rapto del emigrante, 2009, linograbado, 22 x 30 pulgadas.

para el estado psicológico. De este ícono cuelgan una vela y un guaje que se usa para transportar agua, sirve como recipiente. Arriba de la Virgen están dos pedazos de maíz, dos granos, que son como las semillas de nosotros aquí en Estados Unidos. En seguida se encuentran dos maíces de los cuales se suspende un tercer maíz que está medio quebrado.

En México teníamos nosotros que almacenar el maíz, se cosechaba lo que era para un año y muchas veces si no se le echaban unas pastillas para curar el maíz, se podía estropear ya que le entraban animalitos, insectos, y se comían todo el maíz de adentro del tambo. Esas pastillas lo que hacían era destruir el gorgojo que es el insecto que entra al maíz y se lo come. Entonces el maíz fragmentado lo hice como una metáfora, si uno no es dedicado y trabaja duro aquí en Estados Unidos se puede echar a perder, por eso el maíz aquí no está entero ni saludable, lo hice medio quebrado, así como que lo mordió un animal. Y en la 
esquina derecha inferior está un grano de maíz con alambre de púas reflejando que en varias oportunidades también uno se puede tropezar y morir.

En el Rapto del emigrante, los dos perros representan a los de la Patrulla Fronteriza que tienen en los puntos de revisión para que huelan las drogas y para otras labores. Y aquí están dirigiendo al inmigrante al diablo. Debajo de estos monstruos hay un limón; en Laredo le decíamos a la migra los "limones," porque se visten de verde, entonces yo uso mucho los limones en referencia a la migra. El inmigrante está casi desnudo, esto refleja que cuando viajan, vienen de sus países con muchas cosas, pero cuando llegan acá, ya vienen casi sin nada, eso es una metáfora también de que las cosas materiales no valen nada. La bolsa de Soriana (o el HEB o Gigante), todos esos supermercados, reflejan el estado económico de México. En el Rapto del emigrante aparece un camino. Esto refleja que muchas veces en el desierto hay rutas, pero esas vías son para rancheros o para la migra para moverse de un lado a otro, pero si te fijas no hay nada alrededor, no hay nada más que postes de teléfono y en ocasiones incontables gente camina por allí, pero al hacerlo dejan sus huellas aumentando sus probabilidades de que la migra los agarre. Pero el camino también es una forma de poder salvarse, porque si están cansados ellos se pueden quedar allí sentados hasta que alguien vaya a recogerlos o a reportarlos. Por eso digo que el camino está allí, es una forma para salvar vidas, pero también para que los inmigrantes sean descubiertos y el sueño americano sea frustrado. Enfatizo en que estas rutas son más para cuando los inmigrantes ya están en las últimas, cuando ya están a punto de morir.

AMO: En tu obra Un peso para el almuerzo vemos a un hombre que podría ser un vagabundo. Está en la calle mendigando "Un peso para el almuerzo" y, aunque su ubicación es ambigua, en el fondo podemos leer un señalamiento que dice "Pobres Street (Calle Pobres)." ¿Es esta una referencia a la fallida promesa del "sueño americano"? Tú has vivido en ambos países, México y los Estados Unidos, y saliste de tu pueblo para venir a la "tierra prometida" como muchos otros. Ahora que has vivido aquí por varios años, ¿aun crees en el "sueño americano"?

JDM: El "sueño americano" sí se ha realizado para mí, eso no lo puedo negar. Me ha llevado a donde yo he querido llegar. Un peso para el almuerzo es sobre la frontera de Nuevo Laredo en Tamaulipas y Laredo en Texas, y acerca de una gran cantidad de gente que se queda enseguida del puente internacional pidiendo dinero para poder sobrevivir cada día, juntar un dinerito, pagar al coyote y poder cruzarse. Muchas veces en el puente internacional en Nuevo Laredo había numerosas personas mendigando, pidiendo dinero, y tenían a sus hijos allí, a veces tocando unas maracas o un acordeón. A mí me daba tristeza y les daba dinero. En esta pieza lo que hice es reflejar un poquito lo que pasa: muchas familias se quedan allí en la frontera de México y en ocasiones primero se cruza el papá y en el cruce muchas veces se muere o lo meten a la cárcel. Otros padres se vienen para Estados Unidos y primero mandan dinero a sus familias, pero después de un tiempo se olvidan de ellas porque encuentran una nueva pareja o simplemente se olvidan de su familia. Entonces Un peso para el almuerzo lo hice para reflejar estos temas y en vez de un niño puse un perro con un gorrito como para tratar de entretener, porque no me gustaría tener un niño allí, porque quiero que mi obra tenga un tono político, pero tampoco que no sea muy fuerte. El perro es un amigo del hombre y los vagabundos tienen muchos perros. Arriba hay dos veladoras con un frijol que tiene una manta en forma del velo de la Virgen María. Atrás en el fondo hay unas casas, como las de Estados Unidos reflejando el lado estadounidense. 


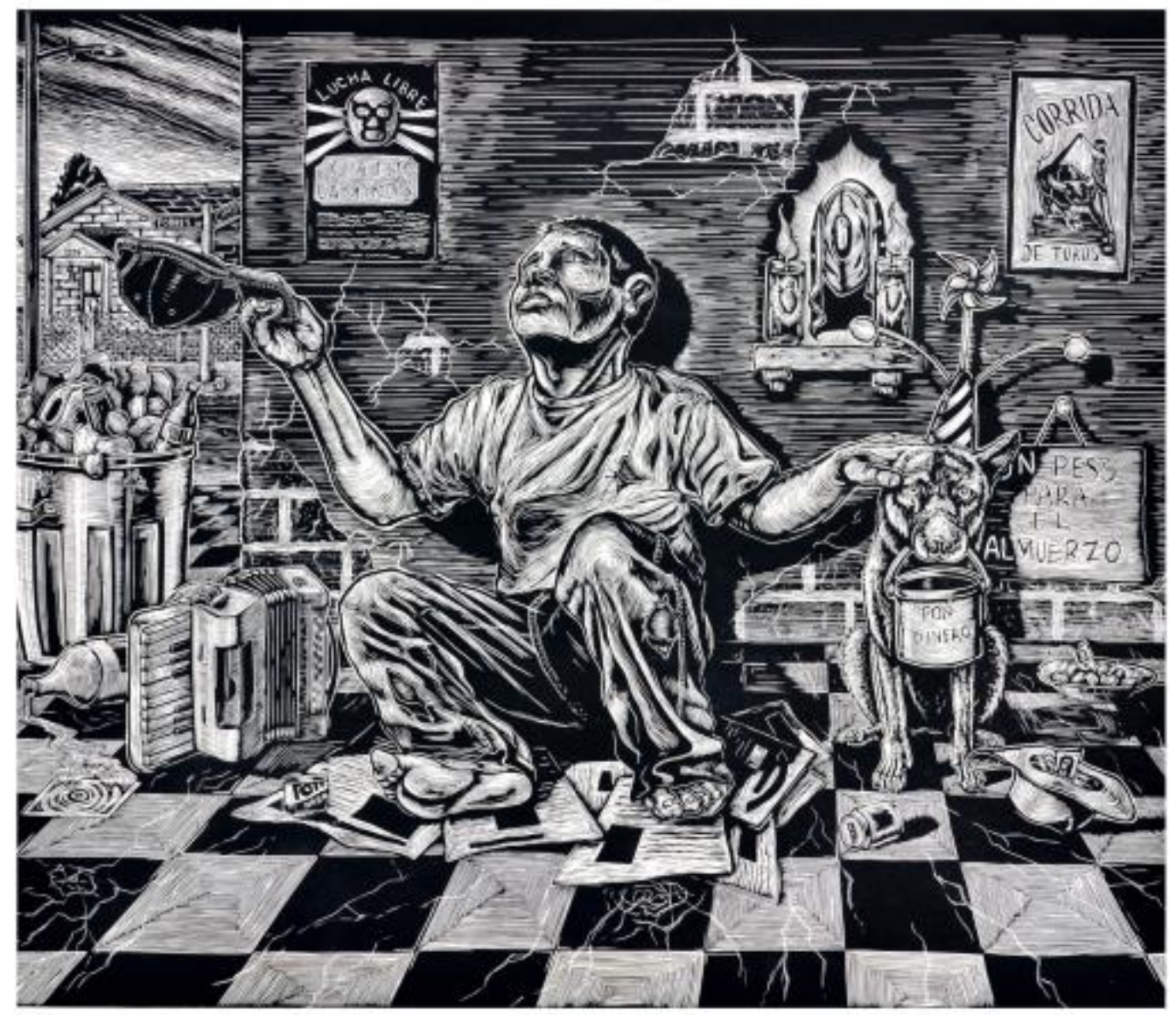

Imagen 4

Juan de Dios Mora, Un peso para el almuerzo, 2010, linograbado, 26 × 27 1/4 pulgadas.

AMO: Juan, en tus grabados podemos observar la túnica de la Virgen de Guadalupe, los pequeños ángeles y las veladoras. ¿Por qué juega un papel tan importante la religión en tu obra?

JDM: La religión es para mantener una actitud positiva y seguir adelante todos los días, para olvidarse de ciertas cosas que son muy sangrientas o para la gente que pierde a su familia. Es más para echarle ganas a la vida y darle para enfrente.

AMO: En tus grabados Asunción del emigrante y en Un peso para el almuerzo vemos cómo un cactus y también frijoles sustituyen la imagen de la Virgen de Guadalupe. Aunque la referencia a México y a su gente es obvia, ¿no crees que esto puede ser ofensivo para una audiencia religiosa?

JDM: Sí, yo crecí en una casa muy religiosa. Cuando empecé a estudiar comencé a ser más liberal, a aceptar a otras culturas y a cuestionar ¿de dónde vengo?, ¿qué es esto?, ¿por qué dicen tal cosa? La religión tiene muchas cosas positivas, pero también tiene otras negativas. La religión mantiene la mente positiva, pero si se considera en extremo en vez de ser una salvación puede ser un veneno y en ocasiones hay que adoptar otras ideas para poder 
sobresalir. Mi objetivo no es ofender, muchas veces yo pongo un frijol para hacer referencia a la situación política, pero yo sé que sí voy a alborotar algo.

AMO: Juan, ¿no crees que el uso de esta planta, el cactus, y esta comida, el frijol, como íconos continúe el uso de estereotipos sobre México?

JDM: Sí, eso no te lo puedo negar y sí la estoy regando, pero muchas veces como artista tienes que liberarte, ser expresivo sobre cómo se siente uno por dentro. En mi familia hacemos burlas intensas a ciertas cosas, tenemos mucho humor, y eso me ayudó a reflejar ese estado de ánimo en mis obras de arte. También lo hago para representar cómo los gringos nos miran a nosotros, como frijoleros, como nopales. Lo hago para describir cómo otro sector demográfico nos percibe.

AMO: El recientemente elegido presidente de los Estados Unidos, Donald Trump, ha dado a conocer varias declaraciones provocadoras en contra de México y su gente. ¿Cómo piensas que los mexicanos deberían interpretar o responder a su discurso, y cómo piensas que un país de inmigrantes, como lo es Estados Unidos, debería reaccionar a tal declamación?

JDM: Lo que debemos hacer es echarle ganas en estos cuatro años. No debemos reaccionar de una forma loca, sino como todos los activistas, hacerlo todo con paz, nada de violencia. En este país todavía existe la discriminación y el odio, es como una forma de despertarnos y de estar conscientes de la situación difícil en la que nos encontramos. Hablamos de la "tierra prometida", pero también está duro, acá vienes a ganar dólares, pero también hay discriminación.

AMO: Juan, ¿hay alguna forma de detener la inmigración hacia Estados Unidos o es el llamado "efecto embudo" siempre presente? ¿Es posible con un muro interrumpir la inmigración? ¿Qué mensaje quieres dar a académicos y a legisladores con tu obra?

JDM: No, no hay forma, eso no se impide, la manera de cruzar de un lado para el otro sólo cambia, pero no para, la gente va a seguir cruzando. La tecnología lo hace más complicado, pero hay formas de poder burlarse de esa tecnología y por tal razón pasa mucha gente. A Estados Unidos lo que le gusta es gastar dinero. Es como los romanos, ellos lo que hacían es que tenían obras de teatro, tenían los gladiadores matando gente para tener a su imperio entretenido, pero también para que le tuvieran fidelidad al imperio. Entonces aquí en Estados Unidos es similar. A nosotros que estamos aquí nos ofrecen muchísimas cosas para estar tranquilos, el muro es para tener calmados a los ciudadanos. Pero nosotros somos resistentes. Yo de manera cómica digo que los inmigrantes somos como los insectos nocturnos, sabemos cómo entrar y salir de un lugar a otro en busca de mejores oportunidades.

AMO: En tu opinión, ¿cuál es o debería ser el papel del gobierno mexicano en referencia a la inmigración y la frontera México-Estados Unidos?

JDM: La forma más cliché es que se provea con más trabajos, formas de empleo, ¿verdad? Que a todos los rancheros les paguen mejor por sus cosechas, que les den más oportunidades, como aquí en Estados Unidos que a todos los que cosechan les dan mejor 
interés para poder pagar una máquina, químicos para echarle a las plantas y mejores impuestos. En México a lo mejor sí hay eso, pero no se puede, como quiera no se puede, yo digo que deberían distribuir más dinero para que puedan sobresalir y sobrevivir cada día.

AMO: Tu obra es de una naturaleza paradójica. Usualmente ofrece un mensaje firme con una crítica severa de la política contemporánea y otros eventos, pero también tiene un sentido del humor. Aportas con detalles inesperados que cambian el tono serio de la obra hacia uno que provoca risa o hasta entretiene. De hecho, en la entrevista con Sabrina Alfaro en el 2013 comentaste, "No me gusta ser político porque creo que hay muchos artistas, yo soy chistoso e intento ser chistoso". " Sin embargo, en Rapto del emigrante, Atacado por los pescados, Asunción del emigrante y Un peso para el almuerzo el humor parece haber desaparecido de la obra. ¿Qué le ha pasado a tu sentido del humor en estos grabados y por qué es el tono de la obra tan serio?

JDM: Estas tres piezas son del 2009-2010 pero ya cambió mucho mi trabajo. Yo a veces no me quiero meter mucho en la política, sin embargo, todos estamos involucrados en ella. Estemos conscientes de eso o no, vivimos con eso, es parte de nuestras vidas. Esto se refleja en mi trabajo, sea chistoso o no. Mi obra a veces ataca a cierto sistema o trata de educar a la comunidad de ciertos problemas que están pasando y que nosotros muchas veces no les hacemos caso, nosotros actuamos con negligencia. Cuando me enfoco en la política lo hago para reflejar lo que es mi cultura y mi comunidad, lo que son los atropellos, la discriminación y hasta la pobreza que en ocasiones ignoramos.

AMO: Generalmente en tus grabados como en La Dust Demonia (2011) y Mi Nave Can Fly! (2011) se puede ver el bilingüismo o el uso de cambio de código del inglés al español que es característico del arte Chicano. ¿Por qué usas spanglish o nada más español, por ejemplo, en Rapto del emigrante o Atacado por los pescados?

JDM: La audiencia es muy importante y si quieres ser más político tienes que ser más directo a la audiencia para que lo pueda entender. En Atacado por los pescados hay unos listones y uno dice, "se me va la vida" y el otro dice "el agua bendita de todos los días". Yo lo estoy haciendo como forma de un mensaje escondido. Es chistoso cuando empiezo a tirar palabras en inglés aquí y allá, empiezo a jugar. Me gusta mucho.

AMO: ¿Qué tan importante es para los inmigrantes el que mantengan su idioma, religión e identidad cultural como tradiciones, celebraciones, comida, música, vestido, literatura?

\footnotetext{
${ }^{6}$ Entrevista llevada a cabo por Sabrina Alfaro el 2 de octubre de 2013 y presentada en la Universidad de Texas de San Antonio el 10 de octubre de 2013.
} 
JDM: Es importante, es lo que nos da la forma de pensar, la manera de sobrevivir y la forma de actuar. Todo eso nos ayuda psicológicamente a echarle muchas más ganas, eso me ayudó bastante a formar parte de lo que soy, a reflejarme de una forma diferente. Nuestra cultura es bellísima. Es muy importante mantener nuestras tradiciones para pasárselas a nuestros niños, el idioma.

AMO: Juan, ¿en qué te encuentras trabajando actualmente? ¿Estas enfatizando otros temas?

JDM: Las nuevas piezas se llaman Soy lo que soy. Es una serie de la gente trabajadora, de cómo trabajan duro en cualquier labor por simple o humilde que sea. Los estoy tratando de poner en una forma heroica, simbólica, como reyes. Por ejemplo, hay un barrendero que está sentado bien orgulloso. Todos tienen un pedestal. Hay otro que se llama La hormiga guerrerita, lo hice cuando íbamos con los niños a los refugios, es un niño y está en una montaña. En vez de un penacho tiene una hormiga, porque las hormigas son bien trabajadoras y siempre siguen un camino. Tiene un ángel y un escudo con un calendario maya y también hay una máscara de un luchador porque en México decimos "échale ganas" o "sigue luchando."

Me gusta mucho decirle a la gente que mi arte es para motivar. Quiero decirle a toda la raza que isí se puede! Echándole ganas se puede. Cualquier carrera que quieran hacer, artista, comunicador de radio, cualquier cosa que sea buena en este mundo se puede. Y que las nuevas generaciones no se olviden de su cultura porque nosotros somos gente trabajadora, no somos de la cultura floja como muchas personas dicen. Hay que seguir motivando a las nuevas generaciones, borrar viejos estereotipos y echarle ganas.

(c) $)$ EY Attribution 4.0 United States License.

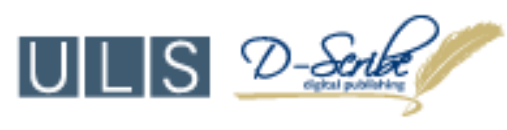

This journal is operated by the University Library System of the University of Pittsburgh as part of its D-Scribe Digital Publishing Program, and is co-sponsored by the University of Pittsburgh Press. 